DOI: $10.19195 / 2353-8546.4 .4$

DOROTA ŻYGADKO-CZOPNIK

Uniwersytet Wrocławski (Wrocław, Polska)

\title{
Backlash, czyli czego obawiają się twórcy najnowszej dramaturgii czeskiej
}

Backlash, or what are the makers of the new Czech drama afraid of. In November 1989 various theater groups participated in overthrowing the totalitarian regime by improvising discussion forums. After the socalled Velvet Revolution, it was the writer and playwright Václav Havel who became head of state while another playwright, Milan Uhde, became the Minister of Culture and Speaker of the Parliament. Nowadays the Czech theater scene is immensely diversified. We can divide the authors who began writing their dramas after 1989 into two generational groups. On the one hand, there are authors born in 1960-1970, who entered the post-totalitarian times already as mature adults and who at the moment have long experience in their artistic work as playwrights, actors or directors (it is quite common that those people write and direct their own work). On the other, there is a younger group which is made of people who were still children during the communist era, and their artistic activity was shaped and took place in most recent years. We are talking about a generation of artists who share a common experience of totalitarianism in childhood and adolescence, as well as the difficult transition between the two systems: communist and capitalist.

Keywords: Czech Republic, theater, drama, artistic work after 1989, generation

Backlash neboli čeho se bojí tvůrci nejnovější české dramaturgie. V listopadu 1989 se v České republice divadelní soubory pořádáním improvizovaných diskuzních fór účastnily svržení totalitního režimu. Po tzv. sametové revoluci stanul v čele státu spisovatel a dramaturg Václav Havel a další dramaturg, Milan Uhde, se stal ministrem kultury a předsedou Poslanecké sněmovny. V současnosti je česká divadelní scéna nesmírně rozrůzněná. Jména autorů, kteří začali svá umělecká díla psát po roce 1989, můžeme rozdělit do dvou generačních skupin. Na jedné straně máme autory narozené v letech 1960-1970, kteří do

* Adres do korespondencji: Zakład Bohemistyki IFS, ul. Pocztowa 9, 53-313 Wrocław. E-mail: zydlo1@wp.pl. 
posttotalitních časů vstoupili už jako dospělí lidé a v současnosti za sebou mají většinou dlouholeté zkušenosti v umělecké práci, nebo v roli autorů dramat, herců př́ípadně režisérů (často se jedná o osoby, které svoje kusy píší a zároveň režírují). Skupinu mladých umělců tvoří lidé divadla, kteří v době komunismu byli ještě dětmi, a jejich umělecká činnost se formuje a připadá na nedávná léta. Je tu řeč o generaci umělců, které spojuje společná zkušenost totalitarismu v dětství a raném mládí a také obtížný přechod mezi dvěma systémy: komunistickým a kapitalistickým.

Klíčová slova: Česko, divadlo, drama, tvorba po roce 1989, generace

Przemiana ustrojowa i przywrócenie swobód demokratycznych musiały wpłynąć na czeskie życie teatralne. Minęło już ponad 25 lat od pamiętnego przełomu roku 1989, który okazał się brzemienny w skutki nie tylko dla czeskiej sceny politycznej. W Czechosłowacji teatr rozwijał się gwałtownie w latach poprzedzających wydarzenia Praskiej Wiosny 1968 roku. Natomiast tuż po nich o awangardzie w teatrze — oraz w jakimkolwiek innym rodzaju sztuki - nie było mowy. Wraz z końcem XX wieku i panującą w nim destrukcją wartości, estetyk i konwencji teatr czeski poszukuje należnego mu miejsca w kulturze. Teatr - sztuka żywa, dziejąca się tylko tu i teraz — zawsze bardzo silnie rezonował lub współbrzmiał z rzeczywistością pozateatralną. Pisząc o stanie obecnej dramaturgii czeskiej po transformacji politycznej w listopadzie 1989 roku, można przywołać metaforę pokoju-rzeczywistości, jaką posługiwał się swego czasu jeden z pionierów polskiej socjologii Gustav Ichheiser ${ }^{1}$. Metafora pokoju-rzeczywistości mówi o kłopotach z rzeczywistością, jakiej doświadczamy, i o różnych sposobach radzenia sobie z opisaniem świata. Chodzi o świat, w którym współczesnym artystom przyszło urodzić się, dorastać, wieść dorosłe życie, kochać i nienawidzić. Wiara w to, że oświetlenie wnętrza pokoju wszelkimi możliwymi kolorami da w efekcie pełny obraz świata, wydaje się błędnym myśleniem. Przeciwnie — wrażenie chaosu jeszcze się pogłębi.

Už nejméně dvacet let se u nás hovoří o krizi divadla, na niž se pak svádí kdejaký propad v oblasti divadelního umění. Sám pocit takové krize je ovšem veden především zastaralými představami, že energii divadlu dodávají nová dramata a bez nich se v divadle nic vývojově závažného nestane².

Do 1989 roku teatr czeski był często miejscem oporu, walki o zachowanie narodowej tożsamości i swobody ducha. Zmiana sytuacji politycznej, jak to określa

${ }^{1}$ Zob. O szansach i pułapkach ponowoczesnego świata. Materialy $z$ seminarium Profesora Zygmunta Baumana w Instytucie Kultury (jesień 1995-wiosna 1996), red. A. Zeidler-Janiszewska, Warszawa 1997, s. 41.

2 „Już co najmniej dwadzieścia lat mówi się u nas o kryzysie teatru, który wini się za wszelki upadek wartości w dziedzinie sztuki teatralnej. Samo poczucie takiego kryzysu jest wywołane przez stare wyobrażenia, że energii teatrowi dodają nowe dramaty, bez których w teatrze nic ewolucyjnie ważnego nie powstanie”. L. Jungmannová, Jak napsat hru nové vlny, „A2 kulturní týdeník” 2006, nr 16, s. 16. 
Jáchym Topol, „wybuchu 1989 roku”3, po tzw. aksamitnej rewolucji w Czechach, przyniosła określone skutki także dla kultury i literatury czeskiej, między innymi zostali dopuszczeni do głosu artyści, którzy za czasów totalitaryzmu nie mogli oficjalnie tworzyć i publikować. Po 1989 roku w kraju doszło z jednej strony do zaniku działalności wielu teatrów tradycyjnych, a z drugiej do powstania nowych scen oraz profesjonalizacji grup amatorskich, poszukujących wówczas swojego widza. Zjawisko to było związane przede wszystkim z wymianą pokoleniową.

Obok powrotów do kraju, wychodzenia z dysydenckiej izolacji i spóźnionego wchodzenia na półki księgarskie występuje wówczas naturalne zjawisko włączania się do procesu literackiego nowych autorów, w większości młodych, którzy nie przeżyli zrywu pokoleniowego „złotych” lat sześćdziesiątych lub przeżyli go jako dzieci ${ }^{4}$.

Zdaniem Agaty Firlej pomocną kategorią w badaniu ich twórczości jest backlash, czyli stan po wybuchu. Kategoria ta wywodzi się z amerykańskiej socjologii.

Backlash jest stanem psychologicznym (również w sensie psychologii społecznej), który skłania do podejmowania decyzji nieracjonalnych i niebezpiecznych, służących wyłącznie zniesieniu poczucia niepewności i tęsknoty ${ }^{5}$.

Mowa tu o pokoleniu twórców będących w podobnym wieku, których poza metryką, łączą także pewne wspólne cechy: podobne „przeżycie pokoleniowe”, czyli określone wydarzenia społeczne, a zarazem polityczne, z których narodziło się ich wspólne postrzeganie rzeczywistości oraz spajająca przedstawicieli tego pokolenia wspólna estetyka, pewna własna poetyka. Niesformalizowane Pokolenie Wielkiej Zmiany ${ }^{6}$ miało możliwość kształtowania świata.

nie mają wspomnień z wojny, nie uczestniczyli w pełnym upojenia budowaniu komunizmu, nie doznali rozczarowania z tego powodu i nie przeżyli zbiorowej euforii „złotych” lat sześćdziesiątych, poczucia wspólnego celu i wspólnej wiary w przemiany społeczno-polityczne. [...] Łączy ich doświadczenie totalitaryzmu w dzieciństwie i wczesnej młodości, a także przejście między dwoma systemami: komunistycznym i kapitalistycznym ${ }^{7}$.

Najmocniejszym doświadczeniem tego pokolenia przełomu było dotknięcie świeżą wolnością: jego przedstawiciele poczuli, że świat stoi przed nimi otworem i mogą realizować własne cele. Zmiana polityczna przyniosła upragnione zniesienie wszelkiej cenzury, co pozwala na swobodny rozwój życia kulturalnego. Wówczas Czesi, po upadku komunistycznego paradygmatu, znaleźli się w nowych warun-

${ }^{3}$ Zob. J. Topol, Siostra, tłum. L. Engelking, Warszawa 2002.

${ }^{4}$ Z. Tarajło-Lipowska, Historia literatury czeskiej. Zarys, Wrocław 2010, s. 450.

${ }^{5}$ A. Firlej, Życie po wybuchu. Refleksy transformacji w czeskiej dramaturgii po 1989 roku, „Bohemistyka” 2012, nr 2, s. 130.

${ }^{6}$ Zob. W. Sokołowski, Portret współczesnego pokolenia - Generacji Wielkiej Zmiany, http://www. epr.pl/portret-wspolczesnego-pokolenia-generacji-wielkiej-zmiany,raporty,37834,1.html [dostęp: 17.12.2014].

7 Z. Tarajło-Lipowska, op. cit., s. 450. 
kach życia społeczno-kulturowego. Według Haliny Janaszek-Ivaničkovej, niezupełnie w takich, jakie zaprojektowali dysydenci i opozycjoniści, zwolennicy otwartego społeczeństwa obywatelskiego.

postkomunistyczna transformacja jest zjawiskiem w dziejach niebywałym, obejmuje swoim zasięgiem prawie 300 milionów Słowian z 12 państw słowiańskich, tj. około 40 procent ludności europejskiej, liczącej w przybliżeniu 726 milionów. W traumatycznej wirówce transformacji, która kręci się w świecie zglobalizowanym i jest jego integralną częścią, formuje się odmienny rodzaj kultury i człowieka człowieka cywilizacji ponowoczesnej, postindustrialnej i światowej. Człowiek ten wyszedł z autarkii komunistycznej i znalazł się w rzeczywistości, na której nadejście nie był przygotowany, w świecie, który zadziwił go tym, że wygląda inaczej niż on to sobie wyobrażał ${ }^{8}$.

W listopadzie 1989 roku zespoły teatralne włączyły się aktywnie w proces obalania reżimu totalitarnego. Jedną $\mathrm{z}$ form walki były organizowane przez nich $\mathrm{w}$ sposób spontaniczny fora dyskusyjne, podczas których aktorzy nawiązywali dyskusje z widzami o potrzebie wprowadzenia zmian politycznych w kraju. Podobne akcje były też organizowane na prowincji poza głównymi ośrodkami fermentu politycznego (Praga, Brno).

W tym czasie wyglądało na to, że każdy nagle chciałby zostać dramaturgiem, czego dowodem była coroczna powódź maszynopisów zgłoszonych do najbardziej prestiżowego konkursu imienia reżysera Alfréda Radoka na oryginalną czeską sztukę teatralną. Jednak z perspektywy czasu można dziś ocenić, że wartych uwagi jest nieco ponad setka sztuk teatralnych autorstwa około piętnastu twórców, urodzonych gdzieś na przełomie lat 60. i 70. W większości mamy do czynienia z twórczością krytykującą stosunki społeczne ${ }^{9}$.

Niekwestionowany lider opozycji antykomunistycznej, a zarazem znany i ceniony (także poza granicami kraju) dramaturg i pisarz Václav Havel, tuż po aksamitnej rewolucji został dziewiątym i ostatnim prezydentem Czechosłowacji, a inny dramaturg Milan Uhde - ministrem kultury i marszałkiem sejmu. Po pierwszych całkowicie wolnych wyborach w 1990 roku Havel pozostał na tym stanowisku. Dla wielu ludzi Havel stał się symbolem współczesnego państwa czeskiego. Dokonał tego poprzez swą walkę z komunizmem. Václav Havel został wybrany na pierwszego prezydenta wolnego kraju. Jego twórczość dramatyczna stała się popularna i legalna w Czechach dopiero w 1989 roku. W następnych latach jego sztuki okazały się prawdziwymi przebojami. W efekcie wydarzeń z 17 listopada 1989 roku znaczna część zakazanych dramaturgów powróciła do teatru. Znaleźli się wśród nich między innymi: Josef Topol, Václav Havel, Milan Uhde, Pavel Kohout, Ivan Klíma, Pavel Landovský, František Pavlíček, Milan Kundera, Daniela Fischerová, Arnošt Goldflam, Ladislav Smoček, Karel Steigerwald. Nowe tytuły dzieł tych autorów należą jednak do rzadkości. Warto wspomnieć na przykład teksty Ladislava Smočka Nejlepší den (1995),

${ }^{8}$ H. Janaszek-Ivaničková, Wstęp, [w:] Literatury słowiańskie po roku 1989. Nowe zjawiska, tendencje, perspektywy. Transformacja, t. 1, red. H. Janaszek-Ivaničková, Warszawa 2005, s. 7.

9 L. Jungmannová, Totalitaryzm i „coolness” - jak to pogodzić?, tłum. K. Krauze, [w:] Opowieści o zwyczajnym szaleństwie. Antologia najnowszej dramaturgii czeskiej, Wrocław 2006, s. 9. 
Pavla Kohouta Nuly (2000), Milana Uhdego Zázrak v černém domě (2007), Václava Havla Odcházení (2008), Danieli Fischerovej Náhlé neštěstí (1993), Fantomima (1993), Pták Ohnivák (2000), Karla Steigerwalda Hoře, hoře, strach, oprátka a jáma (1990), Nobel (1994). Jednak sztuki tych artystów w latach dziewięćdziesiątych XX wieku nie spotkały się już z takim oddźwiękiem, jak ich twórczość wcześniejsza.

Kiedy wraz z upadkiem komunizmu w Czechach wielkie marzenie o wolności wreszcie się ziściło, teatr, kroczący dotychczas na czele pochodu, niespodziewanie pogubił się. Przestał być miejscem, w którym wprost lub za pomocą skomplikowanego systemu symboli i aluzji mówiło się prawdę i zachęcało do walki o zniesienie cenzury, o wolność myślenia i wypowiadania się na temat demokracji i pełnej suwerenności. Teraz nikt już nie oczekiwał od teatru wypełniania politycznej misji. Poza tym w systemie wolnorynkowym, który w Czechach ukształtował się wraz z demokracją, kultura, a więc i teatr, musiały podporządkować się regułom rynku. Pojawiła się pilna potrzeba przedefiniowania miejsca i roli teatru oraz wyznaczenia nowych zadań dopasowanych do wymogów i oczekiwań ówczesnej publiczności. Wolność w teatrze przyniosła konieczność przewartościowań przede wszystkim w dziedzinie dramaturgii.

Autorów, którzy zaczęli pisać swoje sztuki po 1989 roku, można podzielić na dwie grupy pokoleniowe. $Z$ jednej strony mamy autorów urodzonych w latach 1960-1970, którzy w czasy posttotalitarne weszli już jako dojrzali ludzie i obecnie w większości mają za sobą wieloletnie doświadczenie w pracy artystycznej w roli dramatopisarzy, aktorów czy reżyserów (często są to osoby, które piszą i reżyserują swoje sztuki). Do tej grupy zaliczyć możemy twórczość: Markéty Bláhovej, Davida Drábka, Jiřego Pokornego, Tomáša Rychetskiego, Romana Sikory, Ivy Volánkovej, Petra Zelenki i wielu innych artystów. Grupę młodszych twórców reprezentują na przykład Miroslav Bambušek, Roman Olekšák, Markéta Rủžičková i inni, którzy w okresie komunistycznego reżimu byli jeszcze dziećmi, a ich działalność artystyczna kształtuje się i przypada na ostatnie lata. W latach dziewięćdziesiątych XX wieku pojawia się w Czechach tak zwany dramat kobiecy reprezentowany przez Lenkę Lagronovą, Markétę Bláhovą i Ivę Volákovą. Obecnie czeska scena teatralna jest niezmiernie zdywersyfikowana. W swojej monografii Přiběhy obyčejných šilenství. „Nová vlna” české dramatiky po roce 1989 Lenka Jungmannová przedstawia dokonania artystyczne większości dramaturgów reprezentujących wspomniane dwie generacje „nowej fali” (twórczość około 40 autorów) ${ }^{10}$.

Założone w 1995 roku brneńskie wydawnictwo Větrné mlyny ${ }^{11}$, którego priorytetem jest oferowanie czytelnikom wartościowych książek o wysokiej jakości ar-

10 Zob. L. Jungmannová, Př́běhy obyčejných šilenství. „Nová vlna” české dramatiky po roce 1989, Praga 2015.

11 Od 2000 roku wydawnictwo i agencja Větrné mlýny organizuje festiwal literacki „Miesiąc czytania autorskiego" (Měsíc autorského čtení). Obecnie jest to jeden z większych festiwali tego typu w Europie Środkowej. Festiwal literacki odbywa się jednocześnie w czterech miastach: Brnie, Koszycach, Ostrawie oraz Wrocławiu. Wydawnictwo Větrné mlýny wydaje około 40 książek rocznie i publi- 
tystycznej, specjalizuje się w publikowaniu tekstów teatralnych, wydaje drukiem przede wszystkim docenione już dzieła autorów znanych i popularnych, także dzięki swoim osiągnięciom filmowym (Alice Nellis, Petr Zelenka), czy pełniących ważne funkcje administracyjne w strukturach teatralnych (Miroslav Bambušek, David Drábek). Wygrana w prestiżowym konkursie dramatycznym im. Alfréda Radoka, który zorganizowano w 1922 roku, może także znacznie przyczynić się do spopularyzowania tekstu (twórczość Luboša Baláka, Jana Antonína Pitínskiego). Tylko wyjątkowo współczesne czeskie dramaty są w kraju wystawiane więcej niż raz (szczególny przypadek stanowią utwory teatralne reżysera Petra Zelenki, którego sztuki grane są z powodzeniem również poza granicami kraju, między innymi w Japonii, Anglii, Rosji, Serbii, na Węgrzech, w Słowacji i Polsce). Należy zaznaczyć, że młodzi twórcy poza środowiskiem teatralnym, a nieraz nawet także tam, często pozostają nieznani. Większość dramatów wydaje agencja Dilia oraz Divadelní ústav (Instytut Teatralny) w Pradze, wydawnictwo Pražská scéna, Studio Ypsilon, Klokočí i in. Sztuki teatralne zamieszczane są również w czasopismach: „Dramatické uměni”" (wychodziło w latach 1987-1990), „Divadelní revue”, „Svět a divadlo”, „Divadelní noviny”, „Orghast” czy „Yorick. Revue současného myšlení o divadelním umění”. We wrześniu 2010 roku rozpoczęło swoją działalność Centrum současné dramatiky (Centrum Dramaturgii Współczesnej). Wówczas w Czechach narodził się projekt (bynajmniej nie jest to instytucja), który realizuje Divadlo Letí i jego partnerzy, w celu wspierania rozwoju współczesnej czeskiej dramaturgii w kraju i za granicą. Partnerami Centrum současné dramatiky są Švandovo divadlo, Divadlo Na zábradlí, Divadlo Komedie, HaDivadlo i Divadelní ústav w Pradze.

Zdaniem Jiříego Trávníčka czeską twórczość polistopadową można podzielić na trzy okresy: czas euforii lat 1989-1992; okres rozczarowania w latach 1993-1999; okres pojednania, czyli poszukiwanie nowej równowagi w latach 2000-200912. W tym czasie można dostrzec kilka wspólnych dla twórców czeskich problemów, wokół których ogniskuje się ich refleksja nad rzeczywistością "po wybuchu”. Do głównych metod i znaków charakteryzujących sztukę teatru w dobie „po wybuchu” należy zaliczyć destrukcję, która przejawia się w strukturze kompozycji i akcji, jako temat w obrazie destrukcji rodziny, obowiązującego systemu wartości, naturalnych stosunków międzyludzkich oraz symbolicznej mozaice ułożonej z fragmentów współczesności. Jednym z pierwszych przedstawicieli tego trendu był scenograf Egon Tobiáš (dotychczas napisał dwadzieścia dziewięć sztuk teatralnych), który we wczesnym dramacie Vojcev (1992) skupia się na ludzkiej beznadziejności losów bohaterów o rysach surrealistyczno-absurdalnych. W swoich sztukach (m.in. Cizinec - 1998, Mal D’or - 2000, Je suis - 2001, Je na čase, aby se TO zmènilo - 2002, Solingen - 2004, Vyšetřování pokračuje - 2005) rezygnuje z węzła dramatycznego,

kuje miesięcznik kulturalny „RozRazil”. Od 2006 roku wydaje także internetowe czasopismo teatralne „RozRazil”, a od 2009 roku serię „Pohlednice”, w której za pomocą fotografii przedstawiane są ciekawe inscenizacje współczesnych czeskich scen teatralnych.

12 Zob. J. Trávníček, Ve studených vodách svobody, „Host” 2010, nr 10, s. 33-38. 
akcja złożona jest z fragmentów rzeczywistości, wizji, snów, poziomy się tu wzajemnie krzyżują, dochodzi do rozproszenia realnej rzeczywistości.

Autor dramatów i „zwykły” czytelnik oraz widz teatralny w Czechach, doświadczony przez ten sam reżim komunistyczny, odczuwa potrzebę refleksji nad współczesnością z jednoczesnym odwołaniem do przeszłości. Szukając odpowiedzi na pytanie, jak współczesna czeska twórczość teatralna ostatnich lat przedstawia dylematy nowoczesnego świata, nie sposób oderwać jej od ponadczterdziestoletniego okresu totalitaryzmu, ponieważ pod względem tematycznym utwory młodej generacji dramaturgów czeskich starają się rozliczyć z jednej strony ze starym, a z drugiej z nowym ustrojem, $\mathrm{z}$ demokracją, która przeniosła do Czech postmodernistyczne poczucie końca historii i wielkich narracji. Twórcy ujawniają swój strach przed światem, który wyraźnie staje się dla nich zagrożeniem. Znakiem tego jest poszukiwanie tożsamości - postaci dramatów są często symbolami, tracą imiona, zamazują się, podlegają procesowi zamiany lub odrzucenia. Współczesny bohater dramatów próbuje dokonać syntezy, stając ponownie wobec konieczności samookreślenia. Autorzy celowo rezygnują z wielkich narracji, nie postrzegają świata poprzez pryzmat przyczynowości, nie chcą być nosicielami wielkiej sztuki. Zdaniem Lenki Jungmannovej właśnie w tym należy doszukiwać się rysów literatury posttotalitarnej ${ }^{13}$.

W latach dziewięćdziesiątych XX wieku w teatrze czeskim dominowały przede wszystkim utwory groteskowe (pozostające pod wpływem sztuk takich reżyserów, jak Arnošt Goldflam i Jan Antoní Pitínský), które cechowała wyraźna obecność kategorii absurdu, elementów karnawalizacji i atmosfera dziwności. Groteskowy świat typowy jest dla utworów Luboša Baláka, którego sztuki (Fanouš a prostitutka - 1995, Smrt Huberta Perny - 1994, Musulman - 1996) dotyczą tematu nieprzyjemnej i nudnej codzienności, która zmienia się w absurdalnie bezsensowne przeżycie, często kończące się śmiercią bohatera. Charakterystycznym rysem twórczości Baláka jest wprowadzenie języka, który staje się zarówno środkiem, jak i tematem dla artysty. Bohaterowie jego utworów utracili więź z innymi, a język służy tutaj jedynie wyrażeniu „niewyrażalnej” pustki. Luboš Balák jest laureatem wielu konkursów teatralnych, otrzymał między innymi trzecią nagrodę w prestiżowym konkursie Alfréda Radoka (1994) za jednoaktówkę Smrt Huberta Perny.

W tym konkursie (jeszcze jako student) wziął udział David Drábek i został jego laureatem w 1994 (sztuka Jana z parku) oraz w 2003 (sztuka Akvabely) w kategorii na najlepszą oryginalną sztukę teatralną. Założył Studio Hořící žirafy (scena studyjna w teatrze Moravské divadlo w Ołomuńcu, która od 2001 roku uzyskała kameralną przestrzeń w budynku Hoříci dom), aby realizować swoje pierwsze studenckie projekty. Mamy tu do czynienia z modelem teatru autorskiego, gdzie autor jest także reżyserem i gdzie tekstowy pierwowzór powstaje dla konkretnego zespołu. Teatr jest dla Drábka przestrzenią metafory i groteski, poprzez które pokazuje bolesne uwikłania współczesnego człowieka.

13 Zob. L. Jungmannová, Jak napsat hru nové vlny, s. 16-17. 
Odczuwam wstręt do rzeczy ekstremistycznych — mówi Drábek — ale właśnie dlatego, że takie rzeczy - na przykład drobnomieszczaństwo i mass media - nam zagrażają, ludzie muszą się bronić, muszą krzyczeć. Teatru, który tego nie robi, nie rozumiem ${ }^{14}$.

Jego rozumienie teatru związane jest $\mathrm{z}$ potrzebą wypowiadania się na aktualne tematy, uporania się z rzeczywistością i poczuciem przerażenia światem współczesnym. Apelu do widza artysta nie opiera na obrazowości i metaforyczności, ale na ataku i prowokacji, nadając inscenizacjom wyraźną postać teatru politycznego. Teatr musi być według niego otwartą, publiczną przestrzenią, a jego celem jest prowokować, budzić wątpliwości, pytania, potrzebę zmiany stereotypów ${ }^{15}$.

W tekstach czeskich napisanych po 1989 roku bardzo często analizowana jest sytuacja, w której współcześni bohaterowie zachowują się irracjonalnie czy wręcz szaleńczo. Postrzegają świat, zarówno ten wielki (miasto, cała planeta) czy też ten mały, prywatny (dom, rodzinne związki), jak i ten najintymniejszy (ich „ja”), jako nieprzyjazny, wrogi, w którym nie potrafią, czy też nie chcą żyć. Tematyka szaleństwa pojawia się w utworach Davida Drábka, Jiř́iego Pokornego, Ivy Volánkovej, Markéty Bláhovej czy Petra Zelenki i Luboša Baláka.

Wiele tekstów i przedstawień można określić pod względem gatunkowym jako absurdalną groteskę ${ }^{16}$, gdzie dominuje autoironia oraz brak kontekstowości. Problem nieakceptowania starych schematów oraz brak sygnałów istnienia nowych zasad odbija się w groteskowej hiperboli, braku szacunku dla tego, co tradycyjne, w oscylowaniu pomiędzy poezją czy nostalgią a kultem agresji. Należy zauważyć, że zainteresowanie motywem szaleństwa stale rośnie i jest często zasadniczym zagadnieniem wielu nowych tekstów dramatycznych. Milan Uhde, jeden z członków komisji prestiżowego konkursu im. Alfréda Radoka, wskazuje na to zjawisko w artykule Očima porotce soutěže o novou hru (2006).

Za zajímavou okolnost však pokládám to, že nemálo textů, a to většinou těch lepších a nejlepších, zachází s motivem šílení a šílenství, a to nikoliv jako nepř́ijemné duševní poruchy provázené tragickými důsledky, ale používá šílenství částečně i jako autorský zorný úhel ${ }^{17}$.

Proces transformacji ustrojowej, to jest przechodzenie od gospodarki socjalistycznej do gospodarki kapitalistycznej, jedynie wzmocnił w Czechach poczucie

${ }^{14}$ D. Drábek, Pływanie synchroniczne. Akvabely, http://www.teatr.kalisz.pl/?page=news\&id=188 [dostęp: 17.12.2014].

15 Zob. T. Lazorčáková, Teatr jako subiektywna wypowiedź o stanie świata. (O strategiach autorskich w czeskim teatrze lat dziewięćdziesiatych), tłum. L. Spyrka, [w:] Punkty widzenia II. Pohledy II. Strategie autorskie w czeskim i polskim teatrze i filmie, red. T. Lazorčáková, E. Wąchocka, Katowice 2004, s. $31-45$.

16 Zob. Česká divadelní hra 90. let, soubor 13 divadelních her ze soutěže Cena Alfréda Radoka 1992 - 2002, red. M. Reslová, Praga 2003.

17 „Za ciekawy uważam fakt, że niemało tekstów, w większości tych lepszych i najlepszych, posługuje się motywem obłąkania i szaleństwa, i to bynajmniej nie jako nieprzyjemnego zaburzenia psychicznego będącego wynikiem tragicznych doświadczeń, ale po części szaleństwo stanowi ich autorski punkt widzenia”. M. Uhde, Očima porotce soutěže o novou hru, „Svět a divadlo” 2006, nr 4, s. 7. 
kompleksu kulturowego, niższości i artystycznego zapóźnienia wobec sztuki Zachodu. Młodzi artyści brutalnie przedstawiają sytuację człowieka, który wyszedł z komunistycznej utopii oraz kompletną degrengoladę współczesnego świata. Powszechna była na początku lat dziewięćdziesiątych XX wieku wśród młodych dramaturgów inspiracja importowanym z Zachodu brutalistycznym nurtem „coolness" ${ }^{\prime 1}$. Nazwy tej na określenie nurtu brutalistycznego czy też ekspresjonistyczno-naturalistycznego używam za Lenką Jungmannovą, która podkreśla, że „czescy twórcy pozostają pod wpływem modnych gatunków i stylów: czarnej groteski, thrillera z rysem komizmu, a przede wszystkim nowej formy społecznie wywrotowej dramaturgii naturalistycznej określanej mianem »coolness«, importowanej do nas z Wielkiej Brytanii i Niemiec [...]"19. Roman Pawłowski we wstępie do antologii najnowszego dramatu polskiego Pokolenie Porno i inne niesmaczne utwory teatralne (2004) używa przymiotnika „niesmaczne” na określenie wspomnianego nurtu. Czeskie sztuki „coolness” są awangardowe w przedstawianiu okrucieństwa i dość ostre w swojej krytyce społecznej, ale kompozycyjnie pozostają konwencjonalne. Jana Hoffmanová w artykule Vliv cool dramatiky a „drsný” jazyk současných českých her do tego gatunku zalicza przede wszystkim sztuki Marka Horoščáka Vařený hlavy aneb „Děvče, tobě na kozách tanči smrt” (2002) i Jiříego Pokornégo Tatka střilí góly (1997). Natomiast Lenka Jungmannová w tekście Totalitaryzm $i$ „coolness”- jak to pogodzić? wymienia w tym kontekście bezkompromisowo krytyczną społecznie twórczość dramatyczną reżysera Miroslava Bambuška, szczególnie jego sztuki Písek (2002) i Porta apostolorum (2004).

W swoich sztukach autorzy dotykają problematyki okrucieństwa w życiu codziennym (sztuka Horoščáka Vařený hlavy aneb „Děvče, tobě na kozách tančí smrt”), dokonują bezlitosnej krytyki głupoty, szowinizmu i ksenofobii Czechów (sztuka Jiřego Pokornégo Tatka stř́li góly) czy też rodzimej konsumpcji (twórczość Bambuški). Według Agaty Firlej problematyka poruszana przez artystów „nowej fali” była przez wielu widzów postrzegana jako ucieczka od czeskości. Polska badaczka dostrzega jednak pewien zwrot ku czeskiej tradycji teatralnej i ku czeskiej tematyce, który nastąpił wraz z końcem poprzedniego wieku i początkiem obecnego.

Obok utworów takich, jak Písek Miroslava Bambuška, wyraźnie nawiązujących do zachodnich brutalistów (choć jednocześnie rejestrujących stan ducha mieszkańca Europy Środkowej w konfrontacji z „obywatelami świata”), pojawiają się niestroniące od elementów surrealistycznych satyry polityczne (Švejkưv vnuk Luboša Baláka i Cesta do Bugulmy Jáchyma Topola) i parafrazy znanych dzieł (David Drábek w Janie $z$ parku żongluje wielkimi tekstami czeskiej kultury) ${ }^{20}$.

18 Zob. J. Hoffmannová, Vliv cool dramatiky a „drsný” jazyk současných českých her, [w:] Otázky českého kánonu. Sborník z III. kongresu literárněvědné bohemistiky, t. 1, red. S. Fedrová, Praga 2006, s. 588-598.

${ }^{19}$ L. Jungmannová, Totalitaryzm i „coolness” - jak to pogodzić?, s. 9.

${ }^{20}$ A. Firlej, op. cit., s. 134. 
Próbę pogodzenia problematyki uniwersalnej z refleksją dotyczącą współczesnych Czech można wyraźnie dostrzec na gruncie czeskiej satyry politycznej (swoistym novum najnowszej dramaturgii). Najważniejszą autorką tego nurtu (zaliczaną również do nurtu dramatu „kobiecego”) jest Iva Volánková dzięki swym farsom Standa má problém (2005) i Paroubek je kamaRath (2005). W obu dramatach politycy, bez względu na poglądy polityczne, przedstawieni zostali w krzywym zwierciadle jako ludzie małostkowi, dyletanci, hołdujący władzy i wyznający kult pieniądza.

Sezon „czeski” na przełomie milenium programowo ma Činoherní studio w Ústí nad Labem (wystawia sztuki Jiřiego Pokornego, Markéty Bláhovej, Lenki Havlíkovej, Zdeňka Jecelína, Miroslava Bambuška i Egona Tobiáša), a w ślad za nim obiera ten kierunek wiele innych teatrów (czeski sezon w Západočeském divadle w miejscowości Cheb, w Divadle Šumperk i in.). Trend ten utrzymuje się mimo silnej konkurencji ze strony utworów literatury zachodniej.

Zmizel bonus za „českost“ a zmizel i bonus za „literaturu”. Těch, kdo jdou primárně za podmanivou knihou, však neubývá. Český spisovatel má však stále „výhodu domácího hřiště”: je to především on, kdo zná očekávání svých čtenárự, kdo se nejlépe orientuje v domácí situaci, kdo zná zdejší tradici i tušené směry př́ítího vývoje ${ }^{21}$.

Pisarze i poeci czescy zapisali się znacząco w historii czeskiego dramatu, wystarczy wspomnieć twórczość Aloisa i Viléma Mrštíków, Josefa i Karla Čapków, Františka Langera, Vítězslava Nezvala, Františka Hrubína i in., ale w latach dziewięćdziesiątych XX wieku takie wzajemne kontakty i inspiracje są sporadyczne. $\mathrm{W}$ następnych dziesięcioleciach sytuacja ulega zmianie. Wystawiane są sztuki będące adaptacją utworów znanych czeskich autorów (np. Michala Viewegha, Jaroslava Rudiša, Ireny Douskovej, Jáchyma Topola, Jiřiego Kratochvila i in.) bądź pisane przez nich na potrzeby teatru.

W okresie polistopadowym spotykamy się w Czechach z dużymi oczekiwaniami krytyki i widzów wobec teatru i dramatu, które nie zostały spełnione, między innymi nie doszło do renesansu teatrów progresywnych ery „złotych lat sześćdziesiątych”, jakimi były na przykład Divadlo Na zábradlí czy Činoherní klub. Nie doszło do powrotu protagonistów tego okresu, jak chociażby Otomara Krejčiego i jego Divadla za branou II. Bardzo wyraźnie odczuwany był brak dobrych, nowych i reprezentatywnych sztuk teatralnych. Doszło do spadku zainteresowania teatrem ze strony czeskiego widza.

Přestože se na scény vrátily hry normalizačním režimem umlčených dramatiků Václava Havla, Josefa Topola, Pavla Landovského, Ivana Klímy, Pavla Kohouta, Milana Uhdeho ad., došlo k výraznému poklesu diváckého zájmu. První polovinu devadesátých let tedy lze označit za dobu výrazné krize

21 „Zniknął bonus za »czeskość«, a zniknął i bonus za »literaturę«. Tych, którzy poszukują wciągającej lektury, wszakże nie brakuje. Pisarz czeski ma jednak wciąż »przewagę w postaci własnego podwórka«: przede wszystkim on jest tym, który zna oczekiwania swoich czytelników, najlepiej orientuje się w sytuacji krajowej, zna tutejsze obyczaje i przypuszczalne kierunki przyszłego rozwoju”. Zob. J. Trávníček, op. cit., s. 38. 
českého dramatu a divadla, a to i z toho důvodu, že šlo o čas nového hledání, určité tvůrčí nejistoty až tápaní některých renomovaných autorských scén (HaDivadlo, Divadlo Husa na provázku, Semafor) ${ }^{22}$.

Po aksamitnej rewolucji nie chodziło już o opozycję: teatr tradycyjny a teatr awangardowy. W latach dziewięćdziesiątych XX wieku obserwujemy symbiozę teatru autorskiego $\mathrm{z}$ teatrem interpretacyjnym. W teatrze dokonało się przejście od estetyki do etyki, od dawnego pytania o formę tworzenia do nowego pytania o istotę życia. Czeska sztuka teatralna po 1989 roku otwiera nieustanną niekompletność znaczeń i co za tym idzie - uzmysławia niewyczerpywalność możliwości. Szkoda tylko, że „většina děl této »nové vlny« tudíž zůstává v rukopise a nelze vyloučit, že jakkoli původně početná, $z$ kultury postupně zřejmě vymizî’23.

22 „Chociaż na sceny powróciły sztuki zakazanych w okresie normalizacyjnego reżimu dramatopisarzy Václava Havla, Josefa Topola, Pavla Landovskiego, Ivana Klímy, Pavla Kohouta, Milana Uhdego i in., doszło do wyraźnego spadku zainteresowania ze strony widzów. Zatem pierwszą połowę lat dziewięćdziesiątych można oznaczyć jako okres wyraźnego kryzysu dramatu i teatru czeskiego, także z tego powodu, że był to czas nowego poszukiwania, pewnej twórczej niepewności wręcz błądzenia po omacku niektórych renomowanych scen autorskich (HaDivadlo, Divadlo Husa na provázku, Semafor)”. L. Machala, Prologomena české polistopadové literatury, „Britské listy” 2011, nr 2, s. 96.

23 „Większość dzieł tej »nowej fali« pozostaje w rękopisie i nie można wykluczyć, że chociaż pierwotnie liczne, to z kultury oczywiście stopniowo znikną". L. Jungmannová, Jak napsat hru nové vlny, s. 17. 